\title{
Performan Puyuh Local Asal Payakumbuh, Bengkulu dan Hasil Persilangannya
}

\author{
Performance of Quail Originating from Payakumbuh, Bengkulu and Their Crosses \\ D. Kaharuddin dan Kususiayah \\ Jurusan Peternakan, Fakultas Pertanian, Universitas Bengkulu \\ Jln. W.R. Supratman Kandang Limun, Bengkulu \\ Email: desiakaharuddin6@gmail.com
}

\begin{abstract}
This experiment was aimed to evaluate the performance of quails originated from Payakumbuh, Bengkulu and resulted of the crosses. Quail parents obtained by hatching 600 quail eggs from Payakumbuh and 600 eggs from Bengkulu and quail crossbreed were the result of hatching eggs result of crossed of 75 female quail Bengkulu with 25 male quails Payakumbuh. The result of experiment showed that there was increase of fertility and hatchability with heterosis value of 16,77 and $15,12 \%$. The weight and weight gain of quails of crosses at two, four and six week higher than the weight of both parents. However, futher researches need to be conducted to improve quail productivity of the crossbreeds
\end{abstract}

Key words : fertility, hatchability, heterosis

\section{ABSTRAK}

Penelitian ini bertujuan untuk mengevaluasi performans puyuh local asal Payakumbuh dan Bengkulu serta hasil persilangannya. Penelitian ini dilaksanakan dikandang unggas Jurusan Peternakan Fakultas Pertanian Universitas Bengkulu.Puyuh tetua didapatkan dengan cara menetas telur puyuh bibit dari Payakumbuh dan Bengkulu masing-masing 600 butir dan puyuh persilangan adalah hasil penetasan telur hasil perkawinan 75 ekor puyuh betina Bengkulu dengan 25 ekor puyuh jantan Payakumbuh. Data yang diperoleh dianalisis secara deskriptif. Hasil penelitian menunjukkan bahwa terjadi peningkatan fertilitas dan daya tetas dengan nilai heterosis masingmasing 16,77 dan $15,12 \%$. Hasil persilangan menghasil berat badan dan pertambahan berat badan pada umur dua, empat dan enam minggu melebihi berat badan pertambahan berat badan kedua tetuanya. Hal ini memberi harapan untuk dapat diproduksi puyuh persilangan ini pada skala besar, namun masih diperlukan penelitian lebih lanjut.

Kata kunci: fertilitas, daya tetas, heterosis

\section{PENDAHULUAN}

Ternak puyuh merupakan ternak yang potensial untuk dikembangkan karena puyuh memiliki beberapa keunggulan diantaranya dapat dipelihara di lahan terbatas, interval generasinya singkat, keragaman dan produktivitasnya tinggi, walaupun demikian puyuh tidak sepopular ternak ayam. Kenyataan menunjukkan bahwa perkembangannya puyuh di Indonesia relative lambat.

$$
\text { Faktor yang menghambat }
$$

perkembangan ternak puyuhantara lain belum tersedianya bibit puyuh komersil yang berkualitas, para peternak biasanya melakukan sendiri pembibitan dengan cara menetaskan telur-telur dari peternakan mereka. Pelaksanaan pembibitan seperti ini terjadi terus menerus tanpa mendatangkan bibit puyuh dari luar, di peternakan puyuh rakyat perkawinan antar puyuh sekerabat (inbreeding) tidak dapat dihindarkan yang berdampak pada penurunan performans reproduksi dan produksi serta banyaknya puyuh cacat yang muncul seperti cacat kaki pengkor.

Kaki pengkor, fertilitas, daya tetas dan daya tahan hidup yang rendah 
merupakan indicator untuk akibat tekanan silang dalam (inbreeding depression), menurut Astuti et al. (1985).

Perbaikan mutu genetik ternak merupakan salah satu faktor penting yang perlu dilakukan dalam peningkatan produktivitas. Persilangan merupakan salah satu dari berbagai cara yang dapat dilakukan untuk memperbaiki mutu genetic. Persilangan adalah perkawinan antar ternak yang tidak berkerabat (Warwick et al., 1990). Persilangan adalah salah satu alternative untuk membentuk keturunan yang diharapkan dapat memunculkan efek komplementer (pengaruh saling melengkapi). Menurut Falconer (1981) selain efek komplementer persilangan juga akan membentuk efek heterosis untuk meningkatkan produktivitas. Heterosis adalah istilah yang digunakan untuk menggambarkan fenomena suatu hasil persilangan yang rata-rata keturunannya melebihi rata-rata kedua tetuanya. Semakin tinggi nilai heterosis maka semakin tinggi peningkatan produktivitas hasil persilangan yang dapat diharapkan. BeBreeder (2002) menyatakan alasan prinsip penggunaan kawin silang (crossbreed) adalah karena adanya fenomena heterosis ini.

Pada penelitian ini dilakukan persilangan antara puyuh lokal Bengkulu dan puyuh lokal asal Payakumbuh Sumatera Barat untuk melihat pengaruh persilangan terhadap keturunannya.

\section{MATERI DAN METODE}

Penelitian ini dilaksanakan di kandang unggas Jurusan Peternakan
Fakultas Pertanian Universitas Bengkulu. Penelitian dimulai dengan menetaskan telur puyuh bibit yang berasal dari Payakumbuh dan Bengkulu masing-masing 600 butir. Penetasan menggunakan dua mesin tetas untuk menghindari pengaruh mesin tetas, masing-masing telur dibagi dua dan ditempatkan pada kedua mesin tetas. Menjelang telur-telur tersebut menetas, mesin tetas diberi sekat dengan kawat supaya hasil penetasan tidak tercampur.

Untuk mengetahui telur non fertile dan embrio mati semua telur yang tidak menetas dipecah satu persatu. Hasil penetasan dipelihara secara terpisah di kandang koloni yang dilengkapi lampu pemanas.Umur enam minggu puyuh jantan asal Payakumbuh dicampur pemeliharaannya (disilangkan) dengan puyuh betina asal Bengkulu dengan ratio 1: 3 (jantan : betina).

Setelah puyuh yang disilangkan berproduksi $50 \%$ maka telur-telurnya dikoleksi dan ditetaskan untuk menghasilkan turunan (generasi 1). Hasil penetasan dipelihara selanjutnya dilakukan pengamatan variabel produksi. Pakan yang digunakan pada penelitian dua macam, untuk puyuh fase starter diberi pakan dengan protein 23\% dan EM 3200 kkal sedangkan puyuh fase layer (produksi) diberi pakan dengan protein $20 \%$ dan $\mathrm{EM}$ 3000 kkal.

\section{Variabel yang Diamati}

Performans reproduksi : bobot telur tetas, fertilitas, daya tetas, bobot tetas, 
embryo mati dan persentase berat tetas dari telur puyuh asal Payakumbuh, telur puyuh Bengkulu dan telur puyuh keturunannya.

Performans Produksi : bobot badan umur $2 \mathrm{mg}$, 4mg, dan $6 \mathrm{mg}$, PBB, konsumsi dan konversi pada puyuh Payakumbuh, Bengkulu dan turunannya.

Data yang terkumpul dianalisis secara deskriptif.

\section{HASIL DAN PEMBAHASAN}

Performans reproduksi puyuh asal Payakumbuh, Bengkulu dan hasil persilangannya disajikan pada Tabel 1 . Dari Tabel 1 terlihat bahwa bahwa berat telur tetas asal Bengkulu lebih berat dari berat telur puyuh asal Payakumbuh, perbedaan berat telur ini disebabkan telur bibit didapatkan dari tempat berbeda yang manajemen dan lingkungannya juga berbeda. Menurut Woodard et al. (1973) faktor-faktor yang menentukan berat telur pada puyuh adalah lingkungan, genetik, pakan, umur dan berat badan induk. Menurut Sopiyana et al. (2011) semakin besar berat badan induk biasanya menghasil telur dengan ukuran yang lebih besar juga. Dewi et al. (2017) menyatakan berat badan induk pada itik berpengaruh terhadap berat telut dan berat tetas tetapi tidak berpengaruh pada fertilitas dan daya tetas. Sementara itu telur yang ditetaskan sama sekali tidak diketahui recording dari masing-masing tuanya. Dari Tabel 1 terlihat bahwa berat telur tetas puyuh hasil persilangan $11,36 \mathrm{~g}$ berat tersebut melebihi rataan berat dari berat telur kedua tetuanya $(11,01)$ dan persilangan ini berhasil meningkatkan berat telur tetas dengan heterosis $3,18 \%$.

Fertilitas dan daya tetas telur asal Bengkulu juga lebih tinggi dari fertilitas dan daya tetas telur asal Payakumbuh, perbedaan ini kemungkinan disebabkan oleh faktor manajemen dan lingkungan pemeliharaan induk seperti kandungan nutirisi tetua, selain hal itu stress selama perjalanan (pengiriman) dan lama penyimpanan (umur telur) juga bisa menyebabkan menurunnya fertilitas. Sa'diah et al. (2015) menyakan bahwa faktor-faktor yang mempengaruhi daya tetas yaitu teknis pada waktu memilih telur tetas, lama penyimpanan dan teknis operasional mesin tetas. Menurut Prasetyo (2006), umur induk dan sex ratio bisa mempengaruhi fertilitas, semakin tua umur induk akan semakin turun fertilitasnya.

Berat tetas (berat DOQ) puyuh asal Bengkulu lebih tinggi karena berat telurnya juga lebih tinggi, hal ini dapat dipahami karena telur puyuh asal Bengkulu juga lebih berat. Kaharuddin (1989) melaporkan bahwa berat telur tetas berkorelasi positif dengan berat tetas, semakin tinggi berat telur tetas maka berat tetas juga akan semakin tinggi. Hermawan (2000) menyatakan bahwa berat telur tetas dapat digunakan sebagai indicator berat tetas, Berat telur yang lebih tinggi menghasilkan berat tetas yang lebih tinggi juga. Berat tetas hasil persilangannya antara puyuh Payakumbuh dengan puyuh Bengkulu meningkat $0,34 \mathrm{~g}$ dari rataan tetua dengan heterosis $4,94 \%$. 
Tabel 1. Performans reproduksi puyuh asal Payakumbuh, Bengkulu dan hasil persilangannya

\begin{tabular}{lccccc}
\hline \multicolumn{1}{c}{ Variabel } & PYK & BKL & $\begin{array}{c}\text { Rataan } \\
\text { Tetua }\end{array}$ & Keturunan & $\begin{array}{c}\text { Heterosis } \\
(\%)\end{array}$ \\
\hline B. T.T $(\mathrm{g})$ & $10,96 \pm 0,56$ & $11,06 \pm 0,32$ & $11,01 \pm 0,32$ & $11,38 \pm 0,36$ & 3,36 \\
Fertilitas $(\%)$ & 78,02 & 84,87 & 81,44 & 95,10 & 16,77 \\
Daya tetas $(\%)$ & 63,41 & 73,07 & 68,24 & 78,56 & 15,12 \\
Bobot tetas $(\mathrm{g})$ & $6,81 \pm 0,47$ & $6,97 \pm 0,34$ & $6,88 \pm 0,40$ & $7,22 \pm 0,41$ & 4,94 \\
E M $(\%)$ & 36,59 & 26,93 & 31,76 & 21,43 & \\
Puyuh cacat $(\%)$ & 5,24 & 9,48 & 7,36 & 1,24 & \\
\hline
\end{tabular}

Keterangan: $\mathrm{PYK}=$ Payakumbuh; $\mathrm{BKL}=$ Bengkulu

Dilihat dari Tabel 1, untuk kejadian kaki pengkor ternyata puyuh Bengkulu lebih banyak dari puyuh asal Payakumbuh yaitu berturut-turut $9,48 \%$ dan $5,24 \%$. Tabel 1 menunjukkan bahwa persilangan berhasil menurunkan angka kematian embryo sebanyak 32,53\%. Persilangan telah memperbaiki komposisi genetic dengan mengurangi homozigositas gen-gen pada puyuh persilangan yang ditunjukkan dengan berkurang jumlah puyuh cacat kaki pengkor menjadi $1,24 \%$, jumlah puyuh cacat puyuh tetua asal Bengkulu yaitu $9,48 \%$ lebih banyak dari puyuh asal Payakumbuh $(5,24 \%)$ hal ini menunjukkan bahwa telur puyuh asal Bengkulu dan Payakumbuh merupakan telur hasil inbreeding.

Tabel 2. Performans berat badan asal puyuh Payakumbuh, Bengkulu dan hasil persilangannya (F1)

\begin{tabular}{lccccc}
\hline \multicolumn{1}{c}{ Variabel } & PYK & BKL & $\begin{array}{c}\text { Rataan } \\
\text { tetua }\end{array}$ & F1 & $\begin{array}{c}\text { Heterosis } \\
(\%)\end{array}$ \\
\hline Rataan BB DOQ & $6,81 \pm 0,47$ & $6,97 \pm 0,34$ & 6,88 & $7,22 \pm 0,35$ & 4,94 \\
Rataan BB 2 mg (g) & $24,18 \pm 5,21$ & $25,16 \pm 4,19$ & 24,67 & $30,71 \pm 3,81$ & 24,48 \\
Rataan BB 4 mg (g) & $73,80 \pm 4,20$ & $0,25 \pm 3,71$ & 72,03 & $85,85 \pm 6,15$ & 26,13 \\
Rataan BB 6 mg (g) & $112,17 \pm 5,78$ & $107,23 \pm 4,12$ & 109,70 & $123,82 \pm 5,45$ & 9,23 \\
\hline
\end{tabular}

Keterangan: PYK = Payakumbuh; $B K L=$ Bengkulu

Pada Tabel 2 disajikan berat badan puyuh penelitian umur dua, empat danenam minggu, berat badan puyuh bertambah dengan bertambahnya umur. Setelah umur dua minggu puyuh Payakumbuh dapat menghasilkan berat badan lebih tinggi dari puyuh Bengkulu.

Persilangan antara puyuh jantan asal Payakumbuh dengan puyuh betina Bengkulu berhasil meningkat berat badan pada F1 umur dua, empat dan enam minggu dengan heterosis berturut-turut 24,48\%, 26,13\% dan 9,23\%. Peningkatan tertinggi terjadi pada puyuh umur empat minggu. Performans pertambahan berat badan (PBB) disajikan pada Tabel 3 rataan PBB tetua (Payakumbuh dan Bengkulu) berkisar antara 17,77 sampai 47,36 gram, dan PBB hasil persilangan (keturunannya) berkisar antara 23,49 sampai 55,14 gram, baik pada kelompok tetua ataupun keturunnanya PBB tertinggi 
diperoleh pada umur empat minggu, pada minggu ke enam PBB sudah menurun, hal ini mungkin disebabkan pada umur limaenam minggu puyuh dalam masa persiapan organ reproduksi sehingga zat nutrisi yang dikonsumsi penggunaan jadi terbagi. Pada varibel PBB ini heterosis tertinggi ditunjukkan oleh PBB umur 2 minggu $(32,19 \%)$ dan terendah dihasilkan oleh PBB umur enam minggu.

Tabel 3. Performans pertambahan berat badan asal puyuh Payakumbuh, Bengkulu dan hasil persilangannya

\begin{tabular}{llllll}
\hline Variabel & PYK & BKL & Rataan & Keturunan & Heterosis (\%) \\
\hline Rataan PBB s/d 2 mg (g) & 17,35 & 18,19 & 17,77 & 23,49 & 32,19 \\
Rataan PBB s/d 4 mg (g) & 49,62 & 45,09 & 47,36 & 55,14 & 16,42 \\
Rataan PBB s/d 6 mg (g) & 30,37 & 36,98 & 33,68 & 37,97 & 12,73 \\
\hline
\end{tabular}

Keterangan: PYK = Payakumbuh; BKL = Bengkulu

Hasil ini sejalan dengan Anggorodi (1995) yang menyatakan bahwa pertumbuhan berlangsung mulai perlahan- lahan kemudian cepat dan pada tahap akhir perlahan kembali yang kemudian berhenti sama sekali.

Tabel 4. Performans konsumsi ransum puyuh Payakumbuh, Bengkulu dan hasil persilangannya

\begin{tabular}{lllll}
\hline Variabel & Pyk & Bkl & Rataan & Keturunan \\
\hline Rataan kons 0-2 mg (g) & 37,68 & 41,78 & 39,73 & 48,12 \\
Rataan kons 2-4 mg (g) & 130,86 & 128,85 & 128,06 & 139,42 \\
Rataan kons 4-6 mg (g) & 148,21 & 155,14 & 151,68 & 158,75
\end{tabular}

Keterangan: Pyk $=$ Payakumbuh; $\mathrm{Bkl}=$ Bengkulu

Performans konsumsi puyuh penelitian diperlihat pada Tabel 4. Konsumsi ransum meningkat seiring dengan bertambahnya umur puyuh. Apabila dibandingkan dengan Tabel 2 tampak bahwa semakin tinggi berat badan semakin banyak pula konsumsinya kecuali puyuh Bengkulu umur enam minggu berat badannya lebih rendah namun konsumsinys lebih banyak. Puyuh hasil persilangan konsumsinya lebih tinggi dari konsumsi tetuanya tetapi berat badannya juga lebih tinggi (Tabel 2). Berat badan merupakan akumulasi hasil metabolisme. Hasil metabolisme didukung oleh banyaknya pakan yang dikonsumsi serta optimalisasi penggunaan pakan. Unggas membutuhkan asupan nutrisi yang cukup untuk meningkatkan bobot tubuhnya pada masa pertumbuhan. Kaharuddin (2007) menyatakan bahwa bobot badan puyuh senantiasa berbanding lurus dengan konsumsi ransum, makin tinggi bobot badannya, makin tinggi pula konsumsi ransumnya.

Konversi ransum sebagai tolak ukur untuk menilai seberapa banyak pakan yang dikonsumsi puyuh untuk mampu 
menjadi jaringan tubuh, yang dinyatakan dengan besarnya berat badan adalah cara yang masih dianggap terbaik. Kurniawan et al. (2015) semakin kecil nilai konversi semakin baik karena menggambarkan bahwa penggunaan ransum semakin efisien. Nilai Konversi ransum penelitian terdapat pada Tabel 5.

Tabel 5. Performans konversi ransum puyuh Payakumbuh, Bengkulu dan hasil persilangannya

\begin{tabular}{lllll}
\hline Variabel & PYK & BKL & Rataan & Keturunan \\
\hline Rataan konv 0-2 mg (g) & 2,17 & 2,30 & 2,24 & 2,05 \\
Rataan konv 2-4 mg (g) & 2,64 & 2,77 & 2,70 & 2,52 \\
Rataan konv 4-6 mg (g) & 4,88 & 4,22 & 4,50 & 4,18 \\
\hline
\end{tabular}

Keterangan: $\mathrm{PYK}=$ Payakumbuh; $\mathrm{BKL}=$ Bengkulu

Dari Tabel 5 tampak bahwa semakin bertambah umur puyuh semakin turun efisiensinya. Umur dua dan empat minggu puyuh asal Payakumbuh lebih efisien daripada puyuh asal Bengkulu, tetapi di minggu ke enam konversi tertinggi ditunjukkan oleh puyuh asal Payakumbuh $(4,88)$. Dari tabel di atas terlihat bahwa persilangan dapat memperbaiki efisiensi ransum pada puyuh penelitian dengan nilai berkisar antara 2,05 - 4,18. Panjaitan et al. (2012) menyatakan bahwa salah satu faktor yang mempengaruhi nilai konversi adalah berat badan.

Menurut Robinson

(1996) persilangan dapat mengkombinasikan gengen dominan dalam keadaan heterozigos, beberapa gen dominan diperoleh dari tetua jantan dan dominan yang lainnya dari tetua yang lain dan kebanyakan gen-gen dominan mempunyai efek yang menguntungkan maka keturunan yang diperoleh akan mempunyai sifat yang lebih baik dibandingkan dengan tetuanya.

\section{KESIMPULAN}

Performans hasil persilangan antara puyuh lokal asal Payakumbuh dan Bengkulu lebih baik dari performans tetua dan heterosis pada pertumbuhan cukup tinggi. Hasil penelitian ini memberi harapan untuk dapat diproduksi telur dan puyuh dari hasil persilangan pada skala besar, namun masih diperlukan penelitian lebih lanjut.

\section{UCAPAN TERIMA KASIH}

Terima kasih kepada DRPM Dikti yang telah mendanai penelitian ini melalui program Hibah Bersaing tahun 2016.

\section{DAFTAR PUSTAKA}

Anggorodi, H.R. 1995 Nutrisi Aneka Ternak Unggas, Jakarta: Gramedia Pustaka Umum.

Astuti, M., T.A. Sucahyono, dan D.T. Sulistiowati. 1985. Pengaruh silang dalam terhadap daya tunas, daya tetas, dan bobot badan pada 
burung puyuh. Fakultas

Peternakan Universitas Gajah

Mada. Yogyakarta.

BeBreeder. 2002. Poultry Breeding /Genetics Is purebred the answer.www.

uoguelph.ca/cgil/page $8 \mathrm{html}, 17$ May 2002.

Dewi, E. P., E. Supjatna dan E. Kurnianto. 2017. Pengaruh bobot badan induk generasi pertama terhadap fertilitas, daya tetas dan bobot tetas pada itik Magelang di satuan kerja itik Banyubiru - Ambarawa. Jurnal Sain Peternakan Indonesia 12 (1): $1-8$.

Falconer, D. S. 1981. Introduction Quantitative Genetics. $2^{\text {nd }}$ Ed. LongmB Group Ltd. London and New York.

Hermawan, A. 2000. Pengaruh bobot dan indeks telur terhadap jenis kelamin anak ayam kampung pada saat menetas. Skripsi. Fakultas Peternakan. IPB. Bogor.

Kaharuddin, D. 1989. Pengaruh bobot telur tetas terhadap bobot tetas, daya tetas, pertambahan berat badan dan angka kematian sampai umur empat minggu pada puyuh (Coturnix-coturnix japonica).

Laporan Penelitian Universitas Bengkulu. Bengkulu.

Kaharuddin, D. 2007. Performans puyuh hasil pembibitan peternakan rakyat di kota Bengkulu, Edisi Khusus, No. 3. Jurnal Ilmu-ilmu Pertanian Indonesia.

Kurniawan, D., E. Widodo, and M.H. Natsir. 2015. Efek penggunaan tepung tomat sebagai bahan pakan terhadap penampilan produksi burung puyuh. Jurnal Ilmu-Ilmu Peternakan. 25 (1): 1-7.

Noor, R. R. 1996. Genetika Ternak . Cetakan I PT. Penebar Swadaya, Jakarta.

North, M. O and D. D. Bell. 1990. Commercial Chicken Production Manual. $4^{\text {th }}$ Ed. Avi Book, Nostrand Reinhold, New York.

Panjaitan, I., A. Sofian and Y. Priabudiman 2012. Suplementasi tepung jangkrik sebagai sumber protein terhadap kinerja burung puyuh (Coturnix-coturnix Japonica). Jurnal Ilmu-ilmu Peternakan. 15 (1): 8-14.

Prasetyo, L.H. 2006. Strategi dan peluang pengembangan pembibitan ternak itik. Wartazoa. 16 (3): 109-115.

Robinson, D. 1996. Models which might explain negative correlation between direct and maternal effects livest. Prod. Sci. 45: 111122.

Sa'diah, I.N., D. Garnida dan A. Musawwir. 2015. Mortalitas embryo dan daya tetas itik Lokal (Anas sp.) berdasarkan pola 
pengaturan temperature mesin tetas. J. Poult. Sci. 4 (3): 1- 12.

Sopiyati, S., Setioko A.R., Yusnandar, M.E. 2011. Identifikasi sifat-sifat kuantitatif dan ukuran tubuh pada itik Tegal, itik Magelang dan itik Damiaking. Lokakarya Nasional Inovasi Teknologi dalam Mendukung Usaha Ternak Unggas Berdayasaing. Balai Penelitian Ternak. Bogor.
Warwick E.J., Astuti J.M. dan W. Hardjosubroto, 1990. Pemuliaan Ternak. Gadjah Mada University Press, Yogyakarta.

Woodard, A.E., H. Abplanalp, W.O. Wilson, and P. Vohra 1973. Japanese Quail Husbandry in The Laboratory (Coturnix-coturnix japonica). Dept. of Avian Science. University of California. Davis. 